\title{
Independensi, Kompetensi, Pengalaman, Gender dan Kualitas Hasil Reviu Auditor Badan Pemeriksa Keuangan di Indonesia
}

\author{
Tum Adriani Sucipto ${ }^{1}$, Nurmala Ahmar ${ }^{2}$ \\ ${ }^{1}$ Universitas Pancasila, Jl. Srengseng Sawah, Jagakarsa, Jakarta Selatan, 12640 \\ ${ }^{2}$ STIE Perbanas Surabaya, Jl. Ngindom Semolo No. 34-36, Surabaya, Jawa Timur 60118
}

INFO ARTIKEL

JEL Classsification:

H83

G28

Keywords:

independence,

competence,

experience, gender,

quality review results.

\section{ABS TRACT}

This study aims to provide empirical evidence and analyze independence, competence, work experience and gender on the quality of LHP study results. The population of this study is a reviewer in the Main Inspectorate of BPK and staff outside the main Inspectorate unit that has revised LHP. The sample in this study was 56 reviewer. The data in this study is the primary data obtained from the answers of questionnaires given to the respondents. Hypothesis testing is done by using multiple regression which has previously tested the validity, reliability and test of classical principle. Test results show achievement and results. Further research can test based on gender groups to find out evidence of experience as a determinant of the quality of the results of the study. This is done with consideration based on the samples tested, where the number of male and female smoothes is not much different, the experience is not proven by the review results.

\begin{abstract}
A B S T R A K
Penelitian ini bertujuan untuk memberikan bukti empiris dan menganalisis pengaruh independensi, kompetensi, pengalaman kerja dan gender terhadap kualitas hasil reviu LHP. Populasi penelitian ini adalah pereviu di lingkungan Inspektorat Utama BPK dan pegawai di luar unit Inspektorat Utama yang pernah melakukan reviu atas LHP. Sampel dalam penelitian ini sebanyak 56 auditor pereviu. Data dalam penelitian ini adalah data primer yang diperoleh dari jawaban kuesioner yang diberikan kepada responden. Pengujian hipotesis dilakukan menggunakan regresi berganda yang sebelumnya telah diuji validitas, reliabilitas dan uji asumsi klasik. Hasil pengujian menunjukkan independensi dan kompetensi mempengaruhi kualitas hasil reviu, namun pengalaman dan gender tidak berpengaruh terhadap kualitas hasil reviu. Penelitian mendatang dapat melakukan pengujian berdasarkan kelompok gender agar diketahui bukti pengaruh pengalaman sebagai determinan kualitas hasil reviu. Hal ini dilakukan dengan pertimbangan berdasarkan sampel yang diuji, dimana jumlah smapel pria dan wanita tidak jauh berbeda, pengalaman tidak terbukti mempengaruhi hasil reviu.
\end{abstract}

*Email Korespondensi: ${ }^{1}$ rini_sucipto@yahoo.com, ${ }^{2}$ nurmala@perbanas.ac.id 


\section{Pendahuluan}

Badan Pemeriksa Keuangan Republik Indonesia (BPK RI) sebagai Supreme Audit Institutions (SAI) Indonesia adalah lembaga pemeriksa eksternal tertinggi (UUD 1945; UU No.17, 2003) yang mempunyai kewenangan untuk melakukan pemeriksaan atas pengelolaan keuangan negara. Pemeriksaan yang dilakukan oleh BPK terdiri atas pemeriksaan keuangan (financial audit), pemeriksaan kinerja (performance audit) dan pemeriksaan dengan tujuan tertentu/PDTT (special purpose audit). Pemeriksaan BPK dilaksanakan berdasarkan standar pemeriksaan yang disusun BPK, setelah berkonsultasi dengan Pemerintah, dan Pemeriksa menyusun Laporan Hasil Pemeriksaan (LHP) setelah pemeriksaan selesai dilakukan (UU No.15, 2004).

Berdasarkan Data Ikhtisar Hasil Pemeriksaan (IHPS), pemeriksaan yang telah dilakukan oleh BPK per jenis pemeriksaan selama tahun 2013 s.d. 2016 adalah sebagai berikut.

Tabel 1. Jumlah Pemeriksaan BPK per Jenis Pemeriksaan Periode Tahun 2013-2016

\begin{tabular}{|c|c|c|c|c|}
\hline \multirow[t]{2}{*}{ Jenis Pemeriksaan } & \multicolumn{4}{|c|}{ Jumlah Pemeriksaan } \\
\hline & 2013 & 2014 & 2015 & 2016 \\
\hline Pemeriksaan Keuangan & 636 & 632 & 642 & 649 \\
\hline Pemeriksaan Kinerja & 167 & 249 & 282 & 324 \\
\hline Pemeriksaan DTT* & 456 & 440 & 446 & 327 \\
\hline Jumlah & 1.259 & 1.321 & 1.370 & 1.300 \\
\hline
\end{tabular}

Sumber: Data IHPS 2013 s.d. 2016

*) tidak termasuk jumlah audit investigasi yang unpublished

Penjaminan mutu pemeriksaan, BPK telah menetapkan dan melaksanakan sistem pengendalian mutu (SPM) atau quality control system. SPM merupakan unsur penting dalam pemerolehan keyakinan yang memadai bahwa pemeriksaan telah mematuhi ketentuan perundang-undangan serta standar dan pedoman pemeriksaan yang ditetapkan BPK. Untuk memperoleh keyakinan yang memadai bahwa SPM tersebut telah mengatur seluruh unsur pengendalian mutu yang diperlukan dan telah dilaksanakan secara konsisten, BPK telah menetapkan dan menyelenggarakan sistem pemerolehan keyakinan mutu (SPKM) atau quality assurance system. Meskipun BPK telah menetapkan pedoman yang mengatur mengenai mutu pelaksanaan pemeriksaan, namun dalam kenyataannya beberapa pemeriksaan BPK digugat dan diragukan kualitasnya oleh auditee. Pada kurun waktu tahun 2009 hingga Februari 2015, tercatat sudah 11 kali BPK digugat ke Pengadilan Perdata, 4 kali digugat ke Pengadilan Tata Usaha Negara (TUN), serta 4 kali mendapat somasi dengan objek gugatan LHP BPK, rekomendasi, dan perhitungan kerugian negara yang dihasilkan BPK. Jalur hukum tersebut ditempuh dengan menggugat Kepala Perwakilan 
Tabel 2. Jumlah Sengketa Hukum Tahun 2009-Februari 2015

\begin{tabular}{cccccccccc}
\hline \multirow{2}{*}{ Perkara } & \multicolumn{7}{c}{ Tahun } & \multirow{2}{*}{ Total } \\
\cline { 2 - 9 } & $\mathbf{2 0 0 9}$ & $\mathbf{2 0 1 0}$ & $\mathbf{2 0 1 1}$ & $\mathbf{2 0 1 2}$ & $\mathbf{2 0 1 3}$ & $\mathbf{2 0 1 4}$ & $\mathbf{2 0 1 5}$ & \\
\hline Perdata & 1 & 1 & 2 & 1 & 2 & 3 & 1 & 11 \\
TUN & - & 2 & 1 & - & - & 1 & - & 4 \\
Somasi & - & - & - & 1 & 3 & - & - & 4 \\
\hline
\end{tabular}

Sumber : Data Direktorat Utama Pembinaan dan Pengembangan Hukum BPK Tahun 2015

Berdasarkan beberapa permasalahan terkait kualitas hasil reviu tersebut, Inspektorat Pemerolehan Keyakinan Mutu Hasil Pemeriksaan (PKMP) selaku unit yang bertugas untuk melakukan reviu pemerolehan keyakinan mutu atas hasil pemeriksaan BPK, dipertanyakan kinerjanya. Berdasarkan kondisi tersebut, mereka diminta untuk segera memperjelas atas permasalahan yang terjadi dengan melakukan reviu atas hasil pemeriksaan terkait. Selain itu, Wakil Ketua BPK dalam keynote speakernya pada kegiatan Sosialisasi Inspektorat Utama di Perwakilan Jawa Timur tanggal 28 Maret 2016 dan Sosialisasi di Perwakilan Sulawesi Barat tanggal 17 April 2017 juga menyampaikan bahwa pemeriksaan yang menjadi core bussines dari BPK perlu direviu (oleh Inspektorat) secara terus menerus dan berkesinambungan sehingga upaya peningkatan kualitas pelaksanaan dan hasil pemeriksaan dapat terus dilakukan dalam rangka memenuhi ekspektasi para stakeholders BPK.

Berdasarkan Keputusan BPK Nomor 3/K/I-XIII.2/07/2014 tanggal 10 Juli 2014 tentang Organisasi dan Tata Kerja Pelaksana (SOTK) BPK sebagaimana telah diubah dengan Keputusan BPK Nomor 1/K/I-XIII.2/2/2016 tentang Perubahan atas Keputusan BPK Nomor 3/K/I-XIII.2/7/2014 tentang Organisasi dan Tata Kerja Pelaksana BPK, Inspektorat Utama d.h.i Inspektorat PKMP menyelenggarakan tugas dan fungsi antara lain perumusan kebijakan dan pelaksanaan pemerolehan keyakinan atas mutu kinerja pemeriksaan, baik pemeriksaan keuangan, kinerja, maupun DTT, mulai dari perencanaan, pelaksanaan, pelaporan, sampai dengan tindak lanjut pemeriksaan. Kegiatan tersebut dilakukan dalam bentuk reviu pemerolehan keyakinan mutu pemeriksaan (PKMP)/quality assurance setelah LHP diterbitkan (cold review) dan dapat dilakukan pada saat proses pemeriksaan (hot review) untuk objek pemeriksaan dengan risiko tinggi (PMP, 2015).

Berdasarkan Petunjuk Teknis Pemerolehan Keyakinan Mutu Pemeriksaan Keuangan dan Kinerja yang telah ditetapkan BPK, tujuan reviu PKMP adalah untuk: 1) memberikan keyakinan apakah pengendalian mutu yang ada telah dipatuhi oleh Tim Pemeriksaan keuangan, kinerja dan DTT, dan 2) mengindentifikasi area perbaikan yang potensial dalam pemeriksaan keuangan, kinerja dan DTT berikutnya. Dengan demikian reviu dinyatakan berkualitas jika dapat memberikan keyakinan bahwa pengendalian mutu yang ada telah dipatuhi oleh Tim Pemeriksaan dan dapat mengindentifikasi area perbaikan yang potensial dalam pemeriksaan. Hasil reviu dinyatakan dalam 4 rating, yang terdiri dari sesuai (S), perlu perbaikan (PP), sebagian tidak sesuai (STS) dan perlu tambahan dukungan terhadap laporan (PTDL).

Berdasarkan rating reviu STS dan PTDL, maka Inspektorat Utama memberikan rekomendasi untuk perbaikan ke depan dan diharapkan kekurangan yang sama tidak akan terjadi lagi di masa yang akan datang. Namun dalam kenyataan, permasalahan-permasalahan yang sama ditemukan lagi dalam reviu berikutnya. Untuk dapat menggali permasalahan dan penyebab sesungguhnya permasalahan yang ditemukan tersebut agar saran perbaikan dapat tepat sasaran, maka pegawai yang ditempatkan 
di unit Inspektorat yang melakukan reviu LHP seharusnya memiliki independensi, kompetensi yang memadai, pengalaman kerja dan dapat bekerja secara profesional tanpa melihat gendernya, untuk dapat menghasilkan kualitas hasil reviu sesuai tujuan reviu PKMP atas LHP.

Sesuai SOTK BPK Nomor 3/K/IXIII.2/07/2014 tanggal 10 Juli 2014, Inspektorat Utama berada dibawah Wakil Ketua, sedangkan Sumber Daya Manusia (SDM) Inspektorat Utama direkrut dan ditempatkan oleh Sekretaris Jenderal BPK d.h.i Biro SDM BPK RI. SDM yang ditempatkan pada unit Inspektorat suatu saat dapat dipindahkan kembali ke unit pemeriksaan yang pernah direviu. Kendala yang terjadi selama ini, ada kekawatiran dari sebagian pegawai yang melaksanakan reviu jika suatu saat akan dipindahkan ke unit pemeriksaan dan ditempatkan dibawah pimpinan yang LHP nya pernah direviu. Demikian juga, beberapa pegawai Inspektorat memiliki kerabat atau bahkan suami/istri yang ditempatkan di unit pemeriksaan yang direviu, sehingga hal tersebut dikhawatirkan akan mengganggu independensi dari pegawai yang melakukan reviu tersebut.

Selama ini SDM yang ditempatkan di Inspektorat belum berdasarkan kompetensi maupun pengalaman kerja yang dibutuhkan. Penempatan SDM di Inspektorat merupakan penempatan rutin pegawai tanpa melihat kompetensi maupun pengalaman SDM yang bersangkutan. Bahkan beberapa personil yang ditempatkan di Inspektorat belum pernah melakukan pemeriksaan atau baru memiliki pengalaman audit yang singkat. Dengan kurangnya kompetensi dan pengalaman kerja pereviu maka dalam mereviu kurang dapat melakukan diskusi untuk menggali penyebab permasalahan, sehingga jika terjadi permasalahan atas LHP yang direviu dikhawatirkan tidak dapat diketahui akar permasalahannya secara tuntas untuk dapat memberikan rekomendasi atau area perbaikan yang tepat.

Kualitas hasil pemeriksaan internal pemerintah dipengaruhi oleh independensi dan kompetensi pemeriksa internal pemerintah. Penelitian-penelitian sebelumnya mengenai independensi dilakukan oleh, (Nadi dan Suputra, 2017; Rahayu dan Suryono, 2016; Ningsih dan Sofianti, 2015; Samsi dkk, 2012; dan Fahdi) menunjukkan bahwa independensi pemeriksa internal berpengaruh signifikan terhadap kualitas audit. Sedangkan menurut, (Fietoria dan Manalu, 2016; Futri dan Juliarsa, 2014; Kovina dan Betri, 2013; dan Tjun dkk, 2012), independensi pemeriksa internal tidak berpengaruh signifikan terhadap kualitas audit.

Penelitian sebelumnya terkait kompetensi yang dilakukan oleh, ( Nadi dan Suputra, 2017; Fietoria dan Manalu, 2016; dan Tjun dkk, 2012) menyatakan bahwa kompetensi pemeriksa internal berpengaruh signifikan terhadap kualitas audit. Sedangkan menurut, (Ningsih dan Sofianti, 2015; Kovina dan Betri, 2013; Samsi dkk, 2012; dan Fahdi) kompetensi pemeriksa internal tidak berpengaruh signifikan terhadap kualitas audit.

Terkait pengalaman kerja, penelitian (Nadi dan Suputra, 2017; Rahayu dan Suryono, 2016; dan Samsi dkk, 2012) mengungkapkan bahwa pengalaman kerja berpengaruh signifikan terhadap kualitas audit. Sedangkan menurut, (Fietoria dan Manalu 2016; Furiady dan Kurnia, 2015; Futri dan Juliarsa, 2014; Kovina dan Betri,2013; dan Fahdi) pengalaman kerja tidak berpengaruh signifikan terhadap kualitas audit.

Selain itu, SDM perempuan yang ditempatkan di Inspektorat Utama terutama unit Inspektorat PKMP cukup banyak, sehingga sering kali terjadi saat penugasan reviu di daerah, beberapa pegawai meminta melakukan reviu di Jakarta atau minimal daerah yang tidak terlalu jauh, karena urusan keluarga dan beberapa alasan lainnya, sehingga komposisi Tim Reviu akhirnya disesuaikan dengan kondisi yang ada. Berdasarkan bezzeting pegawai Inspektorat PKMP per 31 Maret 2017, dari 36 orang pegawai, sebanyak 20 orang adalah wanita dan 16 orang pria, dengan komposisi sebagai berikut. 
Tabel 3. Jumlah dan Komposisi Pegawai Inspektorat PKMP Per 31 Maret 2017

\begin{tabular}{clrrr}
\hline No & \multicolumn{1}{c}{ Jabatan } & Jumlah (orang) & Pria (orang) & Wanita (orang) \\
\hline 1 & Inspektur PKMP & 1 & 1 & - \\
2 & Kepala Bidang & 3 & 1 & 2 \\
3 & Kepala Sub Bidang & 7 & 1 & 6 \\
4 & Staf & 25 & 13 & 12 \\
Total Pegawai Inspektorat PKMP & 36 & 16 & 20 \\
\hline
\end{tabular}

Sumber: Data Pegawai Inspektorat PKMP

Selain komposisi gender, jumlah SDM yang ditempatkan di unit Inspektorat PKMP berjumlah 36 orang, tidak seimbang dengan jumlah LHP yang seharusnya direviu setiap tahun. Jumlah LHP yang dapat direviu setiap tahun berjumlah antara 1.259 s.d 1.370 LHP (data LHP yang diterbitkan oleh BPK dari Tahun 2013 s.d 2016 sesuai tabel 1.1). Praktek yang dilakukan selama ini, kemampuan per orang untuk mereviu satu LHP adalah 10 hari kerja, karena reviu dilakukan secara menyeluruh atas proses kinerja pemeriksaan dari tahap perencanaan, pelaksanaan, pelaporan, pengendalian mutu menyeluruh dan tindak lanjut. Jika ada kekurangan SDM, Inspektorat PKMP dapat meminta bantuan personil ke satker lain untuk membantu reviu namun permintaan bantuan tersebut disesuaikan dengan anggaran yang ada. Dengan jumlah SDM yang terbatas tersebut, diharapkan unit Inspektorat PKMP dapat memenuhi harapan Pimpinan BPK dalam menjamin mutu kualitas hasil pemeriksaan BPK, sehingga Inspektorat PKMP menetapkan strategi risk base dalam penetapan sampel LHP yang direviu.

Berdasarkan penelitian, (Ningsih dan Sofianti, 2015; Widiarta, 2013; dan Salsabila dan Prayudiawan, 2011) gender (jenis kelamin) tidak berpengaruh pada kualitas audit. Sedangkan berdasar penelitian Indayani dkk, (2015), gender berpengaruh positif dan signifikan terhadap kualitas audit.

Berdasarkan latar belakang tersebut, maka peneliti ingin meneliti ulang pengaruh independensi, kompetensi, pengalaman kerja, dan gender terhadap kualitas hasil reviu atas LHP dengan menggunakan instrumen pengukuran yang dikembangkan peneliti.

\section{Kajian Teori dan Pengembangan Hipotesis}

\section{Pengaruh Independensi Terhadap Kualitas Hasil Reviu LHP}

Menurut Mulyadi (1998), independensi adalah sikap mental yang bebas dari pengaruh, tidak dikendalikan oleh pihak lain dan tidak tergantung pada orang lain. Bagi auditor, independensi merupakan sikap yang melekat pada dirinya dan harus dijaga dalam penugasan profesional audit sejak penyusunan program hingga pelaporan pekerjaannya sehingga independensi seperti telah menjadi syarat mutlak yang harus dimiliki.

Hasil penelitian Nadi dan Suputra (2017) menyatakan independensi berpengaruh pada kualitas audit. Artinya independensi yang dimiliki auditor akan mempengaruhi hasil auditnya dan apakah hasil yang diberikan tersebut ada kecurangan atau telah dilaksanakan secara jujur akan terlihat pada hasil auditnya. Ningsih dan Sofianti (2015) mengungkapkan bahwa independensi berpengaruh terhadap kualitas audit. Audit dikatakan berkualitas jika hasilnya mampu membuat penggunaannya mengambil keputusan dengan tepat. Sikap independen auditor dibutuhkan agar auditor tidak mudah terpengaruh dengan pihak-pihak tertentu yang ingin mengambil keuntungan sendiri. Auditor yang independen juga akan melaporkan semua deteksi kesalahan yang ditemukan selama audit, melakukan pertimbangan-pertimbangan dengan 
tepat tanpa dipengaruhi oleh pihak siapapun sehingga auditor dapat membuktikan kesahihan angka-angka yang disajikan dan melaporkan sesuai kenyataan.

Demikian juga penelitian Samsi dan Suryono (2012) menyatakan independensi berpengaruh positif terhadap kualitas hasil pemeriksaan. Hal ini berarti bahwa kualitas audit dapat dicapai jika auditor memiliki independensi dalam melaksanakan tugas auditnya. Berdasarkan penjelasan tersebut maka hipotesa yang dibangun adalah :

H1: Independensi auditor berpengaruh positif terhadap kualitas hasil reviu LHP.

\section{Pengaruh Kompetensi Terhadap Kualitas Hasil Reviu LHP}

Kompetensi bagi auditor mempunyai dua dimensi yaitu pengalaman dan pengetahuan. Auditor yang semakin berpengalaman dalam penugasan profesional audit akan dianggap mempunyai kompetensi yang tinggi. Selain itu auditor yang selalu meningkatkan pengetahuan tentang audit dan ilmu pendukungnya maka akan dianggap mempunyai kompetensi yang tinggi pula.

Kompetensi yang dibutuhkan dalam melakukan audit yaitu pengetahuan dan kemampuan.Auditorharusmemilikipengetahuan untuk memahami entitas yang diaudit, kemudian auditor harus memiliki kemampuan untuk bekerja sama dalam tim serta kemampuan dalam menganalisa permasalahan. Penelitian Nadi dan Suputra (2017) mengungkapkan semakin tinggi kompetensi auditor menyebabkan hasil kerjanya sangat baik. Demikian juga Fietoria dan Manalu (2016) menyatakan bahwa kompetensi auditor berpengaruh positif pada kualitas audit, sehingga semakin tinggi kompetensi auditor akan semakin baik kualitas audit yang dihasilkannya. Berdasarkan penjelasan diatas maka hipotesis yang dibangun adalah :

H2: kompetensi auditor berpengaruh positif terhadap kualitas hasil reviu LHP

\section{Pengaruh Pengalaman Kerja Terhadap Kualitas Hasil Reviu LHP}

Penelitian Nadi dan Suputra (2017) mengungkapkan bahwa pengalaman auditor berpengaruh positif pada kualitas audit. Hal ini menunjukkan bahwa semakin berpengalaman auditor, menyebabkan semakin baiknya audit yang dihasilkan. Demikian juga Rahayu dan Suryono (2016) mengungkapkan pengalaman auditor berpengaruh positip dan signifikan terhadap kualitas audit. Berdasarkan penjelasan diatas, maka hipotesis yang diajukan adalah:

H3: Pengalaman kerja berpengaruh positif terhadap kualitas hasil reviu LHP.

\section{Pengaruh Gender Terhadap Kualitas Hasil Reviu LHP}

Bidang akuntan publik merupakan salah satu bidang kerja yang paling sulit bagi perempuan karena intensitas pekerjaannya (Ningsih, 2015). Meski demikian, bidang ini adalah bidang yang sangat potensial terhadap perubahan yang dapat meningkatkan lapangan pekerjaan bagi perempuan. Schwartz mengungkapkan bahwa sangat mudah untuk mengetahui mengapa jumlah wanita yang menjadi partner lebih sedikit dibandingkan dengan laki-laki. Salah satu alasan yang dikemukakannya adalah adanya kebudayaan yang diciptakan untuk laki laki, kemudian adanya stereotype tentang perempuan, terutama adanya pendapat yang menyatakan bahwa perempuan mempunyai komitmen pada keluarga yang lebih besar daripada komitmen terhadap karir.

Hasil Penelitian yang dilakukan Indayani (2015) menyatakan bahwa gender berpengaruh positif pada kualitas audit. Perbedaan gender antara laki-laki dan perempuan dengan perbedaan berbagai sifat dan karakter individu masing-masing berpengaruh positif terhadap kualitas audit yang diambil oleh auditor pria dan wanita dalam melakukan tugas audit. Berdasarkan penjelasan di atas dapat diajukan rumusan hipotesis sebagai berikut: 
$\mathrm{H}$ : Gender berpengaruh positif terhadap kualitas hasil reviu LHP.

\section{Metode}

Data dalam penelitian ini diperoleh dari data primer melalui metode survei. Populasi penelitian ini adalah seluruh individu yang terdapat di Inspektorat Utama BPK RI (tidak terbatas pada pegawai Inspektorat PKMP) dan unit terkait yang pernah melakukan reviu LHP. Pemilihan sampel pada penelitian ini menggunakan metode nonprobabilitas, elemenelemen populasi tidak mempunyai kesempatan yang sama untuk terpilih menjadi sampel. Penelitian ini menggunakan metode purposive sampling yang informasi sampelnya diperoleh dengan menggunakan pertimbangan tertentu atau berdasarkan kriteria-kriteria. Pemilihan sampel penelitian secara purposive sampling adalah populasi yang dijadikan sampel merupakan populasi yang memenuhi kriteria tertentu dengan tujuan untuk mendapatkan sampel yang representative sesuai dengan kriteria yang digunakan untuk memilih sampel dari seluruh individu yang masuk dalam kategori.

Variabel dependen adalah variabel terikat atau variabel yang dapat dipengaruhi oleh faktor-faktor lain atau tergantung pada variabel independen. Dalam penelitian ini yang akan menjadi variabel dependen adalah Kualitas Hasil Reviu LHP. Variabel independen adalah variabel bebas atau variabel yang berdiri sendiri atau tidak tergantung pada variabel lain. Variabel independen dalam penelitian ini adalah independensi, kompetensi, pengalaman kerja dan gender.

Independensi adalah cara pandang yang tidak memihak di dalam perencanaan, pelaksanaan pengujian, dan penyusunan laporan. Sikap mental independen tersebut harus meliputi Independence in fact (independensi dalam kenyataan) dan independence in appearance (independensi dalam penampilan). Kompetensi adalah kualifikasi yang dibutuhkan oleh auditor untuk melakukan audit dengan benar. Semakin banyak kompetensi yang dimiliki oleh auditor maka semakin meningkat pula kualitas audityang dihasilkannya, baik kompeten secara personal, memiliki pengetahuan umum maupun keahlian khusus. Kompetensi menjadikan auditor lebih peka dan lebih dapat melakukan penilaian dalam pengambilan keputusan secara tepat sehingga data-data ataupun hasil audit/reviu yang diambil oleh auditor dapat diandalkan oleh para pemakai hasil audit/reviu tersebut. Pengalaman kerja adalah merupakan lamanya waktu dalam bekerja di bidangnya. Manfaat pengukuran pengalaman didasarkan pada asumsi bahwa dengan mengerjakan suatu tugas berulangkali, maka akan memberikan kesempatan mengerjakannya dengan lebih baik. Selain itu pengalaman termasuk juga pernah melakukan bidang yang sama dengan bidang yang diaudit/ reviu. Gender adalah penggolongan secara gramatikal terhadap kata-kata benda dan katakata lain yang berkaitan dengannya, yang secara garis besar berhubungan dengan keberadaan dua jenis kelamin serta ketiadaan jenis kelamin atau kenetralan, yaitu pria dan wanita.

Pengujian dilakukan dengan menggunakan bantuan SPSS mencakup, uji validitas, uji reliabilitas, uji asumsi klasik, uji model (Uji F) dan uji hipotesis t. Hipotesis dibuktikan dengan hasil uji t.

\section{Hasil Penelitian dan Pembahasan}

Analisis dan pembahasan tentang pengaruh independensi, kompetensi, pengalaman dan gender terhadap kualitas hasil reviu didiawali dengan uji asumsi klasik mencakup uji normalitas, uji multikolinearitas, dan uji hetroskedastisitas. Hasil uji asumsi klasik menunjukkan bahwa model yang diuji terbebas dari penyakit asumsi klasik. Rangkuman hasil uji model penelitian (Uji koefisien determinasi dan uji F), terangkum pada table berikut: 
Tabel 3. Rangkuman Hasil Pengujian

\begin{tabular}{cccc}
\hline Keterangan & $\mathrm{B}$ & $\mathrm{T}$ hitung & $\mathrm{p}$. sig \\
\hline Independensi & .172 & 4.303 & .023 \\
Kompetensi & .462 & 2.335 & .002 \\
Pengalaman & .025 & 3.330 & .517 \\
Gender & -.058 & .652 & .268 \\
(Constant) & 1.497 & -1.120 & .000 \\
F-hitung & 12.657 & & \\
Sig.Uji F & $.000^{\mathrm{a}}$ & & \\
Adjt-R2 & 0.459 & & \\
\hline
\end{tabular}

\section{Pengaruh Independensi terhadap Kualitas Hasil Reviu LHP}

Hasil uji partial (uji t) menunjukkan bahwa independensi memiliki pengaruh signifikan terhadap kualitas hasil reviu LHP. Dalam proses reviu tidak dibenarkan memihak kepada siapapun, baik sejak tahap penyusunan program perencanaan, pelaksanaan pekerjaan maupun pelaporan hasil reviu, karena apabila seorang pereviu kehilangan sikap independensinya maka pereviu tidak dapat mempertahankan kebebasan pendapatnya.

Hasil penelitian ini sejalan dengan penelitian Syamsi dkk (2012) yang menyatakan bahwa kualitas hasil pemeriksaan dapat dicapai jika auditor independen dalam melaksanakan tugas auditnya. Sementara Fahdi menemukan bahwa semakin independen seorang auditor maka semakin meningkat atau semakin baik kualitas hasil pemeriksaan yang dilakukannya. Demikian juga Nadi dan Suputra (2017) mengungkapkan bahwa independensi berpengaruh positif pada kualitas audit. Artinya independensi yang dimiliki auditor baik akan mempengaruhi hasil auditnya, dan apakah hasil yang diberikan tersebut ada unsur kecurangan atau telah dilaksanakan dengan jujur akan terlihat pada hasil auditnya.

Peraturan BPK Nomor 1 Tahun 2017 tentang SPKN menyatakan bahwa independensi adalah suatu sikap dan tindakan dalam melaksanakan pemeriksaan untuk tidak memihak kepada siapapun dan tidak dipengaruhi oleh siapapun.
Namun demikian penelitian ini tidak sejalan dengan penelitian Fietoria dan Manalu (2016) yang mengatakan bahwa auditor tidak bisa menjaga sikap independensinya yaitu sikap netral dan menghindari konflik kepentingan dalam merencanakan, melaksanakan dan melaporkan pekerjaan yang dilakukan. Sementara penelitian Futri dan Juliarsa (2014) menyatakan bahwa independensi tidak berpengaruh terhadap kualitas audit dikarenakan ketika mengukur independensi auditor tidak diturunkan dari sikap mental auditor.

\section{Pengaruh Kompetensi terhadap Kualitas Hasil Reviu LHP}

Hasil uji partial (uji t) menunjukkan bahwa kompetensi berpengaruh pada kualitas hasil reviu LHP. Suatu reviu dapat dikatakan berkualitas jika seorang pereviu memiliki kompetensi baik dari segi mutu personal maupun keahlian khusus. Hasil penelitian ini sejalan dengan penelitian Nadi dan Suputra (2017) yang mengungkapkan bahwa kompetensi berpengaruh pada kualitas audit. Artinya semakin tinggi kompetensi auditor maka hasil kerjanya akan sangat baik, dan jika kompetensi auditor kurang baik, hasil kerjanya juga kurang baik. Demikian juga Tjun dkk (2012), menyatakan bahwa kompetensi berpengaruh pada kualitas audit. Kualitas audit dapat dicapai jika auditor memiliki kompetensi yang baik. Auditor sebagai ujung tombak pelaksanaan tugas audit harus senantiasa meningkatkan pengetahuan yang telah dimiliki agar penerapan pengetahuan dapat maksimal dalam prakteknya.

Peraturan BPK Nomor 1 Tahun 2017 tentang SPKN menyatakan bahwa kompetensi adalah pendidikan, pengetahuan, pengalaman, dan/atau keahlian yang dimiliki seseorang, baik tentang pemeriksaan maupun tentang hal-hal atau bidang tertentu. Elemen terpenting bagi pemeriksa adalah mempertahankan kecakapan profesional melalui komitmen untuk belajar dan pengembangan dalam seluruh kehidupan profesional pemeriksa. 
Namun demikian penelitian ini tidak sejalan dengan Ningsih dan Sofianti (2015) yang menyatakan kompetensi tidak berpengaruh terhadap kualitas audit. Kompetensi auditor tidak selamanya menjamin bahwa jasa audit yang dihasilkan akan berkualitas. Setinggi apapun kompetensi auditor, tidak akan bernilai jika tidak disertai dengan sikap independennya karena akan mempengaruhi kemampuan dan kebebasannya dalam memberikan opini. Demikian juga Samsi, dkk (2012) menyatakan kompetensi tidak berpengaruh pada kualitas hasil pemeriksaan. Hal tersebut berkaitan dengan pola rekruitmen pegawai yang bertugas sebagai auditor, agar dalam penempatan pegawai memperhatikan persyaratan dan kriteria seorang auditor. Misalnya latar belakang, pendidikan, dan pengetahuan yang menunjang tugas audit.

\section{Pengaruh Pengalaman Kerja terhadap Kualitas Hasil Reviu LHP}

Hasil uji partial (uji t) menunjukkan bahwa Pengalaman Kerja tidak berpengaruh terhadap Kualitas Hasil Reviu LHP. Pengalaman kerja yang lama tidak dapat diyakini mampu meningkatkan kualitas hasil reviu. Hasil penelitian ini konsisten dengan Futri dan Juliarsa (2014) yang mengungkapkan bahwa pengalaman tidak berpengaruh terhadap hasil audit namun jika auditor sering menghadapi tugas yang kompleks maka akan semakin bertambah pengalaman dan pengetahuannya. Hasil penelitian ini tidak mendukung penelitian Nadi dan Suputra (2017) yang menyatakan jika auditor memiliki pengalaman audit yang banyak akan mempermudah dan mempercepat kerja seorang auditor dalam melaksanakan tugasnya. Demikian juga Rahayu dan Suryono (2016) mengungkapkan bahwa semakin lama masa kerja yang dimiliki auditor maka akan semakin baik dan meningkat kualitas audit yang dihasilkan.

Dari penelitian yang pernah dilakukan, pengalaman kerja diduga berpengaruh terhadap kualitas hasil audit/reviu yang dilakukan.
Pengalaman kerja erat kaitannya dengan lama masa kerja dan banyaknya pemeriksaan yang dilakukan auditor. Semakin lama masa kerja sebagai auditor maka akan mempengaruhi profesionalismenya. Pengalaman merupakan salah satu sumber peningkatan keahlian auditor yang dapat berasal dari pengalaman-pengalaman dalam bidang audit dan akuntansi. Pengalaman tersebut dapat diperoleh melalui proses yang bertahap, contohnya: pelaksanaan tugas-tugas pemeriksaan, pelatihan ataupun kegiatan lain yang berkaitan dengan pengembangan keahlian auditor. Pengalaman auditor akan terus meningkat seiring dengan makin banyaknya audit yang dilakukan serta kompleksitas tugas.

Dalam penelitian ini, pengalaman kerja dilihat dari beberapa dimensi, yaitu:

1. Masa kerja di BPK

Masa kerja di BPK terbagi dalam lima tahunan sesuai dengan pemberian penghargaan pegawai dalam masa 10 tahun, 20 tahun dan 30 tahun.

2. Masa kerja di Inspektorat Utama

Masa kerja maksimal dalam satu unit adalah 4 tahun, sehingga jarak masa kerja terbagi tahunan.

3. Jumlah audit yang pernah dilakukan

Audit yang dapat dilakukan oleh seorang auditor maksimal 5 kali setahun, yaitu audit keuangan, kinerja, Dengan Tujuan Tertentu, kerugian negara dan pemantauan tindak lanjut.

4. Jumlah reviu yang pernah dilakukan.

Reviu atas LHP yang dapat dilakukan selama setahun adalah 3 kali, yaitu reviu pada wilayah pusat, BPK perwakilan wilayah Barat dan BPK Perwakilan wilayah Timur.

Hasil penelitian menunjukkan bahwa pengalaman kerja tidak berpengaruh terhadap kualitas hasil reviu. Hal tersebut dapat terjadi karena walaupun seorang pereviu memiliki pengalaman yang banyak dalam arti masa kerja cukup lama, bukan berarti yang bersangkutan dapat meningkatkan kualitas hasil reviu atas 
LHP. Untuk dapat mereviu dengan baik dan sesuai tujuan reviu, maka seorang pereviu harus diberikan kursus atau pelatihan yang cukup memadai untuk dapat menunjang pekerjaannya. Selain itu seorang pereviu seharusnya sudah pernah melakukan audit untuk menghasilkan LHP yang berkualitas sehingga dalam mereviu telah paham hal-hal apa yang perlu diperdalam dalam reviu sehingga kualitas reviu nya meningkat.

\section{Pengaruh Gender terhadap Kualitas Hasil Reviu LHP}

Hasil uji partial (uji t) menunjukkan bahwa Gender tidak berpengaruh terhadap kualitas hasil reviu LHP. Kualitas hasil reviu tidak dipengaruhi oleh pereviu baik laki - laki maupun perempuan. Hasil penelitian ini konsisten dengan penelitian Ningsih dan Sofianti (2015) yang mengungkapkan bahwa perbedaan jenis kelamin antara pria dan wanita dengan perbedaan berbagai sifat dan karakter individu masing-masing tidak berpengaruh terhadap audit judgement yang berhubungan dengan kualitas audit yang diambil oleh auditor pria dan wanita. Widiarta (2013) juga mengungkapkan bahwa tidak ada perbedaan yang signifikan tentang kualitas audit dilihat dari sisi gender. Demikian juga Salsabila dan Prayudiawan (2011) mengungkapkan bahwa gender tidak mempengaruhi kualitas hasil kerja auditor internal karena pria atau wanita samasama mencurahkan kemampuan dan tanggung jawabnya sebagai auditor pemerintah, sehingga pria atau wanita dapat menghasilkan hasil kerja yang berkualitas tanpa memandang status gender auditor. Oleh karena itu, gender bukanlah penghalang untuk dapat menghasilkan pekerjaan audit yang berkualitas.

Hasil penelitian ini tidak mendukung penelitian Indayani dkk (2015), yang mengungkapkan bahwa gender berpengaruh terhadap kualitas audit. Wanita pada umumnya memiliki tingkat pertimbangan moral yang lebih tinggi daripada pria. Pertimbangan moral yang dimaksudkan adalah sebagai langkah pengambilan keputusan dan informasi dalam mengaudit. Laki-laki dalam pengolahan informasi biasanya tidak menggunakan seluruh informasi yang tersedia sehingga keputusan yang diambil kurang komprehensif dan hasil kerjanya kurang baik. Sedangkan perempuan lebih teliti dalam menggunakan informasi yang lebih lengkap dan mengevaluasi kembali informasi dan tidak gampang menyerah. Perempuan relatif lebih efisien dibandingkan laki-laki dalam mendapat akses informasi. Selain itu, perempuan juga memiliki daya ingat yang lebih tajam terhadap suatu informasi baru dibandingkan kaum laki-laki.

Hasil penelitian menunjukkan bahwa gender tidak berpengaruh terhadap kualitas hasil reviu. Hal tersebut dapat terjadi karena dalam melakukan reviu, baik wanita maupun pria mendapat porsi penugasan dan tanggung jawab yang sama dan masing-masing pereviu dapat meningkatkan kemampuannya mereviu. Tidak ada pembatasan dalam peningkatan kemampuan masing-masing pereviu laki-laki maupun perempuan. Demikian juga fasilitas yang diberikan dalam penugasan, tidak ada perbedaan antara pereviu laki-laki dengan pereviu perempuan.

\section{Simpulan}

Kualitas hasil reviu dipengaruhi oleh indepensi, kompetensi, pengalaman, dan gender secara teoritis. Pengujian dilakukan dengan sampel 56 pereviu yang memiliki pengalaman melakukan reviu LHP. Hasil pengujian menunjukkan terdapat pengaruh yang signifikan antara independensi terhadap kualitas hasil reviu LHP secara parsial. Terganggunya independensi akan mempengaruhi kualitas hasil reviu LHP. Artinya untuk memperoleh hasil reviu LHP yang berkualitas maka seorang pereviu harus memiliki independensi baik pada saat penyusunan program, pelaksanaan reviu maupun pelaporan hasil reviu, sehingga hasil reviu sesuai dengan kondisi yang senyatanya dan dapat memberikan rekomendasi sesuai permasalahan yang 
ditemukan. Dengan demikian maka reviu LHP yang dilakukan dapat meningkatkan kinerja pemeriksaan serta memberikan perbaikan dalam pelaksanaan pemeriksaan kedepannya. Hasil penelitian menunjukkan bahwa kompetensi mempengaruhi kualitas hasil reviu, sementara pengalaman dan gender tidak berpengaruh terhadap kualitas hasil reviu.

Jumlah pereviu yang ada di satuan kerja inspektorat utama sangat terbatas sehingga responden dari luar inspektorat utama dimasukkan sebagai sampel, meskipun baru satu kali melakukan reviu LHP. Keragaman pengalaman menyebabkan persepsi responden terhadap pertanyaan-pertanyaan dalam kuesioner tidak sama, sehingga dimungkinkan dipengaruhi unsur subyektifitas. Penelitian mendatang sebaiknya meilih sampel yang lebih homogeny dan dapat menambahkan variable lain didalam model karena kemampuan menjelaskan variable belum tinggi.

\section{Daftar Referensi}

Ahimsyah, (2016), Pengaruh Lokus Kendali, Komitmen Profesi, Turnover Intention dan Perilaku Disfungsional Audit terhadap Perilaku Disfungsional Audit, Program Pasca Sarjana Magister Akuntansi, Universitas Pancasila Jakarta Badan Pemeriksa Keuangan Republik Indonesia, (2013), Ikhtisar Hasil Pemeriksaan Semester I Tahun 2013.

Badan Pemeriksa Keuangan Republik Indonesia, (2014), Ikhtisar Hasil Pemeriksaan Semester II Tahun 2013.

Badan Pemeriksa Keuangan Republik Indonesia, (2014), Ikhtisar Hasil Pemeriksaan Semester I Tahun 2014.

Badan Pemeriksa Keuangan Republik Indonesia, (2015), Ikhtisar Hasil Pemeriksaan Semester II Tahun 2014

Badan Pemeriksa Keuangan Republik Indonesia, (2015), Keputusan BPK RI Nomor 5/K/1-XIII.2/10/2015 tentang Panduan Manajemen Pemeriksaan
Badan Pemeriksa Keuangan Republik Indonesia, (2015), Ikhtisar Hasil Pemeriksaan Semester I Tahun 2015.

Badan Pemeriksa Keuangan Republik Indonesia, (2016), Ikhtisar Hasil Pemeriksaan Semester II Tahun 2015.

Badan Pemeriksa Keuangan Republik Indonesia, (2016), Keputusan BPK RI Nomor 1/K/1-XIII.2/02/2016 tentang Perubahan atas Keputusan BPK Nomor 3/K/1XIII.2/07/2014 tentang Organisasi dan Tata Kerja Pelaksana BPK.

Badan Pemeriksa Keuangan Republik Indonesia, (2016), Keputusan Sekjen BPK RI Nomor 109/K/X-XIII.2/3/2016 tentang Petunjuk Teknis Pemerolehan Keyakinan Mutu atas Pemeriksaan Keuangan,

Badan Pemeriksa Keuangan Republik Indonesia,

(2016), Keputusan Sekjen BPK RI Nomor 110/K/X-XIII.2/3/2016 tentang Petunjuk Teknis Pemerolehan Keyakinan Mutu atas Pemeriksaan Kinerja.

Badan Pemeriksa Keuangan Republik Indonesia, (2016), Ikhtisar Hasil Pemeriksaan Semester I Tahun 2016.

Badan Pemeriksa Keuangan Republik Indonesia, (2017), Ikhtisar Hasil Pemeriksaan Semester II Tahun 2016.

Badan Pemeriksa Keuangan Republik Indonesia, (2017), Peraturan BPK RI Nomor 1 Tahun 2017 tentang Standar Pemeriksaan Keuangan Negara.

Fahdi, M, Pengaruh Pengalaman Kerja, Independensi, Obyektifitas, Integritas, Kompetensi, dan Motivasi Terhadap Kualitas Hasil Pemeriksaan.

Fietoria dan Manalu, E.S., (2016), Pengaruh Profesionalisme, Independensi, Kompetensi, dan Pengalaman Kerja Terhadap Kualitas Audit di Kantor Akuntan Publik Bandung, Jurnal of Accounting and Business Studies, Vol. 1, No. 1, September 2016.

Furiady, O., dan Kurnia, R., (2015). The Effect of Work Experiences, Competency, 
Motivation, Accountability and Objectivity Toward Audit Quality, Procedia - Social and Behavioral Sciences 211 (2015) 328 335.

Futri, P.T., dan Juliarsa, G., (2014). Pengaruh Independensi, Profesionalisme, Tingkat Pendidikan, Etika Profesi, Pengalaman, dan Kepuasan Kerja Auditor Terhadap Kualitas Audit pada Kantor Akuntan Publik di Bali, e-Jurnal Akuntansi Udayana 8.1 : 41 -58.

Indayani, P.,I., Sujana, E., dan Sulindawati, N. L. G.E., (2015). Pengaruh Gender, Tingkat Pendidikan Formal, Pengalaman Kerja Auditor Terhadap Kualitas Audit (Studi Empiris pada Kantor Inspektorat Kota Denpasar, Kabupaten Badung dan Kabupaten Buleleng), e-Jurnal Ak. Universitas Pendidikan Ganesha, Volume 3 Nomor 2 Tahun 2015.

Kovinna, F dan Betri, (2013). Pengaruh Independensi, Pengalaman Kerja, Kompetensi, dan Etika Auditor Terhadap Kualitas Audit (Studi Kasus pada Kantor Akuntan Publik di Kota Palembang), Jurusan Akuntansi, STIE MDP.

Nadi, I.M.P.P., dan Suputra, I.D.G.D, (2017). Pengaruh Kompetensi, Pengalaman, Independensi dan Motivasi Auditor pada Kualitas Audit, e-Jurnal Akuntansi Universitas Udayana, Vo. 18.2. Februari 2017 : 942-964.

Ningsih, S. dan Sofianti, S.P.D, (2015). Pengaruh Kompetensi, Independensi dan Jenis Kelamin Auditor Terhadap Kualitas Audit
Dengan Kecerdasan Emosional Sebagai Variabel Moderasi : Study Empiris pada Kantor Akuntan Publik di Malang, Artikel Ilmiah Mahasiswa, Universitas Jember.

Rahayu, T., dan Suryono, B., (2016). Pengaruh Independensi Auditor, Etika Auditor, dan Pengalaman Auditor Terhadap Kualitas Audit, Jurnal Ilmu dan Riset Akuntansi, Volume 5, Nomor 4, April 2016.

Republik Indonesia, (2004), Undang-undang Nomor 15 Tahun 2004 tentang Pemeriksaan Pengelolaan dan Tanggung Jawab Keuangan Negara

Salsabila, A dan Prayudiawan, H., (2011). Pengaruh Akuntabilitas, Pengetahuan Auditor dan Gender Terhadap Kualitas Hasil Kerja Auditor Internal (Study Empiris pada Inspektorat Wilayah Propinsi DKI Jakarta), Jurnal Telaah \& Riset Akuntansi, Vol.4 No.1, Juli 2011, Hal : 155-175.

Tim Dosen Pembimbing Tesis Pogram Studi Magister Akuntansi Universitas Pancasila, (2014), Pedoman Penulisan Tesis, Jakarta.

Tjun, L.T., Marpaung, E.I., dan Setiawan, S., (2012). Pengaruh Kompetensi dan Independensi Auditor Terhadap Kualitas Audit, Jurnal Akuntansi, Vol.4 No.1, Mei 2012, 33-56, Universitas Kristen Maranatha.

Widiarta, (2013). Pengaruh Gender, Umur dan Kompleksitas Tugas Auditor pada Kualitas Audit Kantor Akuntan Publik di Bali, e-Jurnal Akuntansi, Universitas Udayana 3.1,109-118. 